Ann. Biol. anim. Bioch. Biophys., 1979, 19 (3 A), 597-605.

\title{
Epididymal sperm maturation in the ram : motility, fertilizing ability and embryonic survival after uterine artificial insemination in the ewe
}

\author{
par Suzanne FOURNIER-DELPECH, G. COLAS, M. COUROT, R. ORTAVANT, \\ G. BRICE \\ with collaboration of C. CORNU, Y. GUÉRIN, Y. LEBRETON
}

Station de Physiologie de la Reproduction, I.N.R.A.

Laboratoire de Fertilité mâle,

Nouzilly 37380 Monnaie, France.

\begin{abstract}
Summary. Ram spermatozoa from the distal caput, corpus, and cauda epididymis and ejaculated spermatozoa were artificially inseminated in 170 ewes which had been treated with an ovulatory dose of PMSG $61 \pm 4 \mathrm{hrs}$ previously. Results were expressed as the percent of ewes pregnant 18 days after insemination $(F=q$ with positive progesterone assay $/$ O

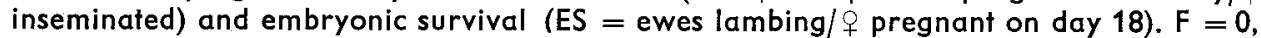
$8,12,54,78,80$ and 72 p. 100 respectively after insemination with $20 \times 10^{6}$ total spermatozoa/horn from the caput, corpus, I, II and III, proximal cauda, distal cauda, and ejaculate. Development of sperm fertilizing ability parallelled the development of sperm motility. However when ewes were inseminated with high number of motile spermatozoa, ES was 0 , $77,86,100$ and 86 p. 100 with spermatozod from the corpus I + II, the corpus III, the proximal cauda, the distal cauda, and the ejaculate respectively. Thus, the sperm from middle corpus are totally unable to produce viable lambs.
\end{abstract}

In the ram the development of sperm fertilizing ability in the epididymis coincides with the development of progressive motility (Fournier-Delpech ef al., 1977) in a maturation process similar to the one described in rodents (reviews of OrgebinCrist ef al., 1975, 1976 ; Bedford, 1975) or in the pig (Holtz and Smidt, 1976 ; Hunter et al., 1976). However, in the rabbit embryonic mortality is increased after fertilization by immature spermatozoa from the corpus epididymis (Orgebin-Crist, 1969 ; OrgebinCrist and Jahad, 1977). Similarly, litfer size in rats is smaller after intra-uterine insemination with epididymal spermatozoa from the corpus than after insemination with spermatozoa from the cauda (Paz et al., 1978).

We attempted to establish the relationship between the motility and fertilizing ability of ram spermatozoa in different parts of the epididymidis and to investigate the embryonic survival after fertilization with epididymal spermatozoa. 


\section{Materials and methods.}

A. Preparation of spermatozoa. - Ejaculated spermatozoa were diluted into skimmed milk and brought to $15^{\circ} \mathrm{C}$ (Colas et al., 1968). Epididymal spermatozoa were obtained from different segments of the epididymidis caput (distal), corpus $(I=$ middle, $I I=$ inferior middle and $I I I=$ distal part), and cauda (proximal and distal) according to Fournier-Delpech ef al. (1977). The sperm density was estimated and the spermatozoa were diluted to a final concentration of $20 \times 10^{6}$ total cells $/ 200 \mu \mathrm{l}$. In some cases spermatozoa from corpus I and II where the percent of motile cells was low, were diluted in a range of concentrations from 0.5 to $20 \times 10^{6}$ motile sperm/ $200 \mu \mathrm{l}$. The percentage of eosin stained spermatozoa was counted under the microscope (150 cells per smear) as described Ortavant ef al. (1953) and the percentage of progressive motile cells as well as their velocity was subjectively evaluated by visual observation under the microscope at $37^{\circ} \mathrm{C}$ at the beginning and end of each series of inseminations.

Artificial inseminations were performed by injecting $200 \mu \mathrm{l}$ of sperm suspension into each uterine horn, 57 to 66 hrs after PMSG injection (Fournier-Delpech et al., 1977).

B. Preparation of ewes. - Ovulation was induced by PMSG as previously described (Colas, 1975). The dose of PMSG varied according to the breed and season : group 1 : Ile-de-France, 50 ㅇ, Autumn 1976, 450 IU ; group 2 : Berrichon du Cher, 35 ㅇ, Spring 1977, 700 IU ; group 3 : Ile-de-France, 68 ㅇ․, Autumn 1977, 450 IU ; and

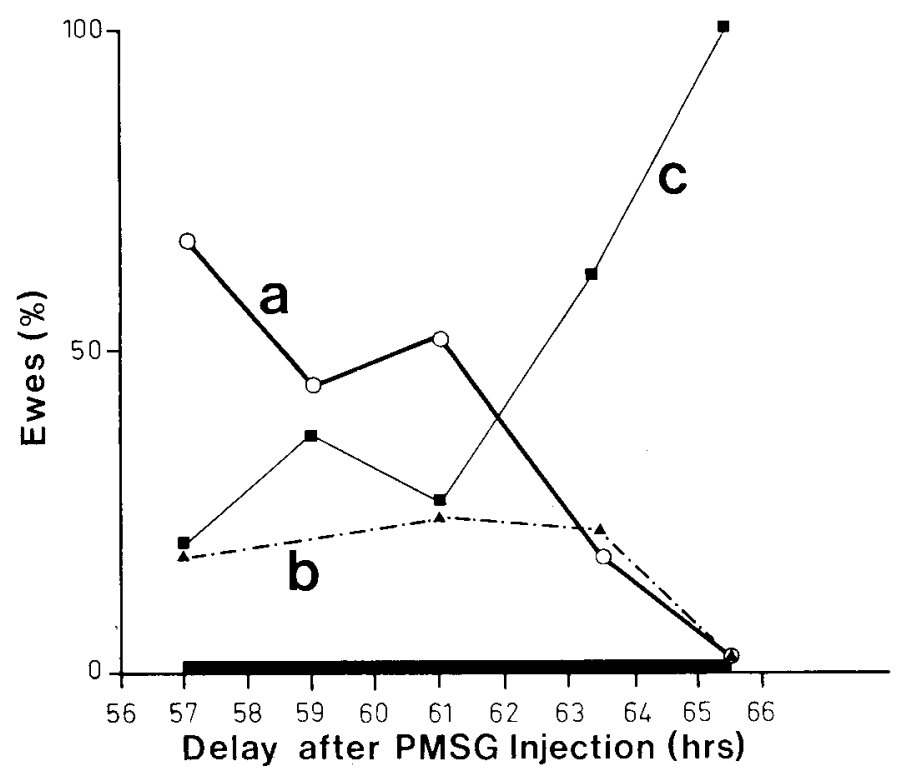

FIG. 1. - Time of ovulation of the ewe after progesiagen-PMSG treatment a) Preovulated stage only ; b) ovulated follicles only ; c) preovulatory and ovulated follicles on the same ewe. - Time of insemination. 
group 4 : Cross-bred (IF or Prealpes $\times$ Romanoff), 17 q, Autumn 1977, 350 IU. At the time of insemination the number of ovulatory follicles were counted.

C. Fertility. - The pregnancy rate $(F) 18$ days after insemination is expressed as the number of ewes pregnant (estimated from the concentration of plasma progesterone - Terqui and Thimonier, 1974) per number of ewes inseminated. Embryonic survival (ES) is expressed as the number of ewes lambing per number of ewes pregnant on Day 18. Analyses were carried out using Fischer's analysis of variance and the chi-square test.

\section{Results.}

A. Ovarian parameters. - The average number (mean $\pm s d$ ) of ovulations per ewe was $1.97 \pm 0.9$ (lle-de-France), $2.38 \pm 0.9$ (Berrichon du Cher) and $2.9 \pm 0.7$ (Cross-bred). The difference between the lle-de-France and Berrichon du Cher ewe was significant $(P<0.05)$. More ovulations were noted on the right than the left ovary $(P<0.05$ ) in both Spring and Autumn (Autumn : $1.21 \pm 0.01$ versus $0.74 \pm 0.01$; Spring : $1.21 \pm 0.17$ versus $0.84 \pm 0.36$ ). Ovulation began 57 hrs after PMSG injection and was completed by 66 hrs (fig. 1).

B. Motility and eosin-stainability of spermatozoa. - The number of eosin-stained cells was higher in the distal corpus epididymidis than in the caput or the cauda : $31 \pm 15$ in the head, $67 \pm 29$ in the distal corpus ; $38 \pm 29$ in the cauda. The percentage of spermatozoa with progressive motility increased between the middle corpus and distal cauda. This increase was greater in Autumn than in Spring (table 1). The velocity of spermatozoa differed depending on the origin; it increased from middle corpus to distal cauda.

\section{TABLE 1}

Seasonal variation in motility of lle-de-France epididymal ram spermatozoa

\begin{tabular}{|c|c|c|c|}
\hline \multirow{2}{*}{ Source of spermatozoa } & \multicolumn{3}{|c|}{ p. 100 of progressive motile spermatozoa } \\
\hline & Autumn $n_{n_{1}}$ & Spring $_{2}$ & $\mathbf{P}$ \\
\hline 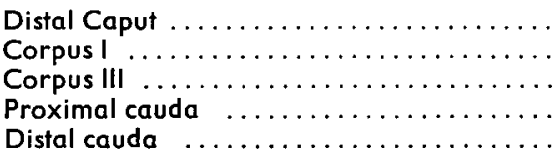 & $\begin{array}{l}1 \pm 0 \\
5 \pm 0 \\
44 \pm 10 \\
70 \pm 20 \\
81 \pm 10\end{array}$ & $\begin{array}{c}0 \\
1 \pm 1 \\
21 \pm 7 \\
55 \pm 15 \\
61 \pm 17\end{array}$ & $\begin{array}{l}0.05 \\
0.05 \\
0.05 \\
\text { NS } \\
\text { NS }\end{array}$ \\
\hline
\end{tabular}

$\mathrm{n} 1=6$ rams; $\mathrm{n} 2=5$ rams; Mean \pm sd.

C. Fertilizing ability of spermatozoa.

1) Pregnancy diagnosis 18 days after insemination of $20 \times 10^{6}$ spermatozoa per horn showed that fertilizing ability develops as spermatozoa pass from the distal caput $(F=0$ p. 100) to the distal cauda ( $F=80$ p. 100) (table 2$)$. 
On Day 18, there is a correlation between the number of motile spermatozoa inseminated and their fertilizing ability ( $r=0.9$ corpus $I, r=0.6$ corpus III) until fertilizing capacity reaches a plateau (fig. 2).

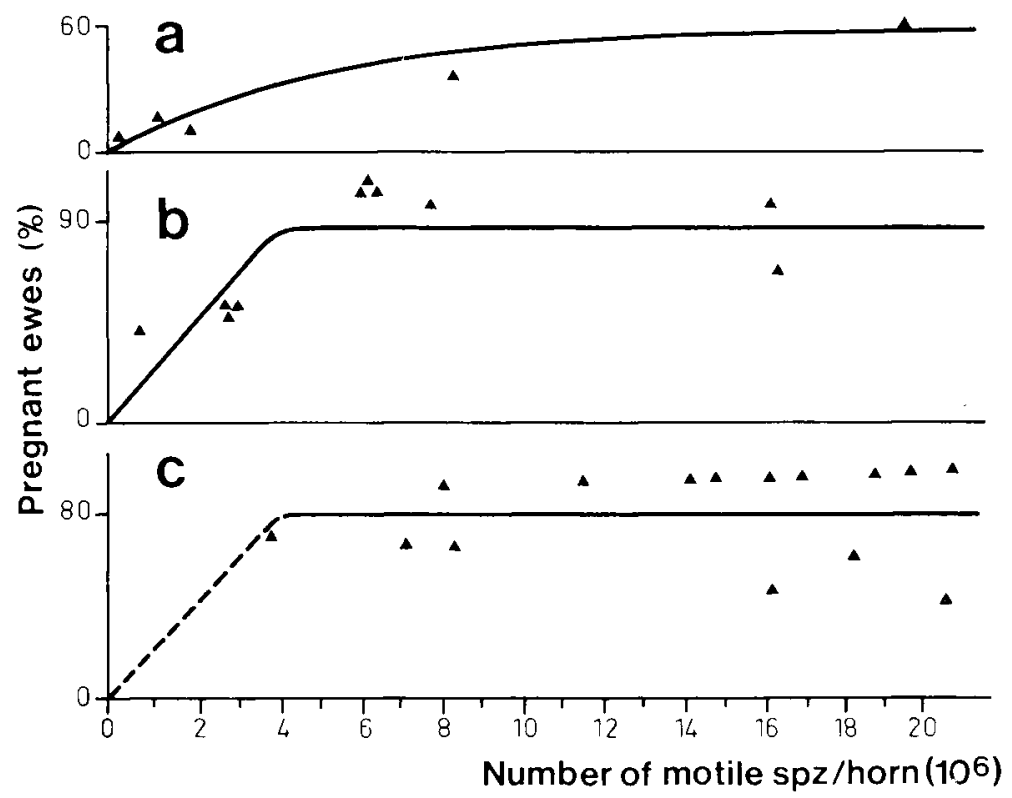

FIG. 2. - Fertilizing ability of motile epididymal spermatozoo

a) spz from corpus I + II ; b) spz from corpus III ; c) spz from the cauda.

2) At the end of gestation embryo survival rate and litter size differed according to the type of epididymal spermatozoa inseminated : embryo survival was optimum after spermatozoa has reached the distal corpus (tables 3 and 4).

TABLE 2

Pregnancy rate (F) 18 days after insemination with epididymal and ejoculated spermatozoa $\left(20 \times 10^{6}\right.$ fotal sperm per horn ; 158 9) 
Litter size was significantly higher $(P<0.05)$ after insemination with spermatozoa from the proximal cauda $1.87 \pm 0.70$ or ejaculate $1.82 \pm 0.75$ than with spermatozoa from the distal corpus (1.33 \pm 0.62 ) (table 4).

\section{TABLE 3}

Embryo loss after insemination of epididymal spermatozoa

\begin{tabular}{|c|c|c|c|c|}
\hline Source of spermatozoa & $\frac{\text { Ewes lambing }}{\text { Ewes pregnant at } 18 \text { days }}$ & $\begin{array}{l}\text { Embryo } \\
\text { survival } \\
\text { (p. 100) }\end{array}$ & \multicolumn{2}{|c|}{$\begin{array}{c}\text { Embryo } \\
\text { loss } \\
\text { (p. 100) }\end{array}$} \\
\hline $\begin{array}{l}\text { Corpus I }+ \text { II } \ldots \ldots \ldots \ldots \ldots \ldots \ldots \ldots \ldots \\
\text { Corpus III } \ldots \ldots \ldots \ldots \ldots \ldots\end{array}$ & $\begin{array}{c}0 / 6 * \\
15 / 19\end{array}$ & $\begin{array}{l}0 \\
77\end{array}$ & $\left.\begin{array}{r}100 \\
23\end{array}\right\}$ & 67 \\
\hline $\begin{array}{l}\text { Proximal cauda } \\
\text { Distal cauda .... }\end{array}$ & $\begin{array}{l}25 / 29 \\
16 / 16\end{array}$ & $\begin{array}{r}86 \\
100\end{array}$ & $\left.\begin{array}{r}14 \\
0\end{array}\right\}$ & 10 \\
\hline Ejaculate $\ldots \ldots \ldots$ & $17 / 21$ & 86 & 14 & \\
\hline
\end{tabular}

* In order to obtain enough $q$ pregnant at 18 days, several ewes have been inseminated with more than $20 \times 10^{6}$ total sperm from corpus I + II thus delivering a sufficient number of motile spermatozoa.

\section{TABLE 4}

Litter size occording to origin of spermatozoa used for insemination

\begin{tabular}{|c|c|c|c|}
\hline Source of spermatozoa & $n$ & $\begin{array}{l}\text { Litter size } \\
\text { (lambs/f) }\end{array}$ & $\begin{array}{c}\text { Ovulations/lambs } \\
\text { (p. 100) }\end{array}$ \\
\hline 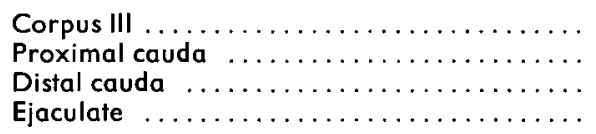 & $\begin{array}{l}15 \\
23 \\
14 \\
11\end{array}$ & $\begin{array}{l}1.33 \pm 0.62 \\
1.87 \pm 0.70 \\
1.57 \pm 0.51 \\
1.82 \pm 0.75\end{array}$ & $\begin{array}{l}69 \\
95 \\
80 \\
92\end{array}$ \\
\hline
\end{tabular}

$\mathrm{n}=$ number of ewes lambing.

\section{Discussion.}

The methods used in this study are the most appropriate for determination of epididymal sperm fertilizing ability in the species studied.

1. Ovulations are routinely obtained and can be visually checked at laparatomy at the time of insemination.

2. Introduction of sperm into the uterine cavity at the utero-fubal junction area improves their efficiency (Lightfoot and Salamon, 1970) : $20 \times 10^{6}$ spermatozoa/horn are sufficient to obtain fertilization, whereas $500 \times 10^{6}$ are required for cervical insemination (Colas, 1975 and 1979 ; Gordon, 1975). In addition, no embryo loss could be related to the technique of surgical intra-uterine insemination as observed by Killeen and Moore (1971) : embryo survival was 100 p. 100 after insemination with 
epididymal sperm from the distal cauda (table 3) and litter size was the same after insemination of ejaculated sperm into the cervix (Colas, 1975 ; Gordon, 1975) and after insemination with ejaculated sperm into the uterus (table 4).

3. The level of progesterone is a sensitive index of pregnancy before implantation (Wintenberger-Torrès, 1978). In our study pre-implantation losses occuring before Day 18 would not be detected and the embryonic losses observed may be underestimated.

The main functional changes undergone by spermatozoa in the epididymidis are the development of progressive motility and fertilizing ability.

1. The capacity for progressive motility in the ram develops as spermatozoa pass through the corpus epididymidis (Fournier-Delpech et al., 1977). The present findings demonstrate a relationship between motility and season into the epididymidis. The percentage of forward moving cells in corpus I and II is significantly lower $(P<0.05)$ in the Spring than Autumn. Therefore, there are seasonal variations not only in the number of spermatozoa produced by the testis (Ortavant, 1958) and entering into the epididymis but also in the development of their motility. A similar seasonal variation has been observed in the fertilizing capacity of ejaculated ram spermatozoa after freezing (Colas and Brice, 1976).

The striking alteration in rate of eosin stained cells probably reflects a most pronounced change in the membrane properties of the spermatozoa during transit through the epididymal corpus (Ortavant, 1953).

2. Fertilizing capacity presents different characteristics at 18 days post-insemination in comparison to lambing results :

a) After insemination with a constant number of spermatozoa $\left(20 \times 10^{6}\right.$ per horn) the pregnancy rate developed constantly which is correlated with the number of progressive motile cells inseminated per horn in the corpus $(r=0.9$ in the middle corpus ; $r=0.6$ in the distal corpus). However, the plateau is reached at a lower motile sperm concentration and the pregnancy rate is higher when more mature spermatozoa are inseminated (fig. 2).

Progressive motility may be the only essential factor to deliver the fertilizing agent to the oocyte for fertilization. However, development of motility is not definite proof of fertilizing ability for a potential fertile sperm. The pregnancy rate showed that ferifilizing ability had not been completely achieved in the middle corpus (60 p. 100 with $20 \times 10^{6}$ motile spermatozoa inseminated/horn from the distal corpus versus 90 p. 100 with $8 \times 10^{6}$ motile spermatozoa from the distal corpus). Consequently, the acquisition of a mature motility pattern may not be sufficient for fertilization.

b) A higher embryonic mortality after insemination with young epididymal spermatozoa has been reported in the rabbit (Orgebin-Crist, 1969) and the pig (Hunter ef al., 1976), but was not observed by Overstreet and Bedford (1976) in the rabbit. We found that 67 p. 100 of the embryos were lost when spermatozoa from the corpus epididymidis were inseminated, whereas, only 10 p. 100 were lost with mature spermatozoa from the cauda or the ejaculate (table 3). No lambs were obtained from 6 ewes found pregnant on Day 18 after insemination with middle corpus sperm. In 
contrast, all 16 pregnant ewes inseminated with cauda sperm and tested at 18 days lambed. Consequently, embryo loss may be related to the male gamete. This confirms earlier reports and clearly shows that immature spermatozoa from middle corpus were unable to produce viable lambs and that the utero-fubal junction is unable to recognize fertile sperm ; it is only a filter of motile cells (Dauzier, 1958).

The increase in litter size from mature caudal sperm may be explained by a decrease in embryo loss after insemination with spermatozoa from the distal part of the epididymidis. Alternatively, it could result from a higher proportion of oocytes fertilized by sperm from the distal corpus versus 80-95 p. 100 with mature caudal epididymal or ejaculated spermatozoa (table 4).

In the rabbit, embryo loss has been explained by the delay of the first cleavage of ova fertilized with immature (proximal corpus) sperm from consistent observations on 359 males rabbits (Orgebin-Crist and Jahad, 1977). Embryo loss from immature spermatozoa may also be related to maturational changes occurring in the sperm nucleus during epididymal transit such as in the nuclear basic proteins (Gledhill, 1971 ; Marushige and Marushige, 1975), disulfide bonds (Bedford, 1974), ADN-Feulgen (Esnault et al., 1975) and pronucleus inhibitor (Ueraha and Yanagimachi,! 1977). The exact mechanism by which the fertilizing capacity of sperm is affected by epididymidis remains conjectural. It is possible that there is a specific epididymal environment necessary for sperm maturation, as could be concluded from the existence of specific proteins (Fournier, 1968 ; Fournier-Delpech ef al., 1973, 1974 ; Koskimies and Kormano, 1975 ; Oscar et al., 1978) and particular metabolism (Voglmayr, 1975 ; Dacheux ef al., 1978). According to studies on the duration of transit of sperm cells along the epididymis (Amir and Ortavant, 1968), it is concluded that fertilizing ability develops in the ram as a rapid event, in a few hours, when spermatozoa leave the middle inferior corpus and reach the distal epididymal corpus. This present study demonstrates that the capacity for the conceprus to develop normally after fertilization depends on maturation of spermatozoa which is only completed after the sperm cells have reached the cauda epididymis.

Reçu en octobre 1978.

Accepté en novembre 1978.

Acknowledgement. - An important part of this work was done as field experiments on sheep farms: We thank Mr and Mme Jeay (Thou, France), Mr. and Mme Barnier (SaintChristophe le Chaudry, France) and Mr. and Mme Oleotto (Levet, France) for their generous help and hospitality.

Résumé. Des spermatozoïdes de la tête distale, du corps et de la queue de l'épididyme ainsi que de l'éjaculat ont été inséminés chirurgicalement $\left(0.5\right.$ à $20 \times 10^{6}$ cellules mobiles/ corne utérine) chez 170 brebis en ovulation induite $61 \pm 4 \mathrm{~h}$ après l'injection de PMSG. Les résultats ont été exprimés par le taux de brebis gestantes à 18 jours $(F=q$ avec diagnostic positif de la progestérone/ P inséminées). Après insémination de $20 \times 10^{6}$ spermatozoïdes totaux, F était respectivement égale à $0,8,12,54,80$ p. 100 après l'insémination de spermatozoïdes de la tête, du corps I, II et III, de la queue proximale et distale ef de l'éjaculat. Le développement des capacités fécondantes des spermatozoïdes est parallèle à celui 
de leur mobilité. Cependant, chez les brebis inséminées avec un nombre élevé de spermatozoïdes mobiles, du corps, suffisant pour obtenir des gestations, la survie embryonnaire fut de $0,77,86,100$ et 86 p. 100 respectivement avec des spermatozoïdes du corps I + II ef III, de la queue proximale et distale et de l'éjaculat.

Ainsi, les spermatozoïdes du corps moyen de l'épididyme sont complètement inaptes à produire des agneaux viables.

\section{References}

AMIR D., ORTAVANT R., 1968 . Influence de la fréquence des collectes sur la durée de transit des spermatozoïdes dans le canal épididymaire de bélier. Ann. Biol. anim. Bioch. Biopinys., 8, 197207.

BEDFORD M., 1974. On the functional significance of S-S cross linkings in heads with particular reference to eutherian mammals, 343-347. In AFZELIUS A. B., The functional anatomy of the spermatozoon. Perg. Press, Oxford and New York.

BEDFORD J. M., 1975. Maturation, transport and fate of spermatozoa in the epididymis, 303-317. In Hamilton D. W., GREEP R. O., Handbook of physiology, Sect. 7, Endocrinology, Vol. 5, Am. Physiol. Soc., Washington DC.

COLAS G., DAUZIER L., COUROT M., ORTAVANT R., SIGNORET J. P., 1968. Résultats obtenus au cours de l'étude de quelques facteurs importants de l'insémination artificielle ovine. Ann. Zootech., 17, 47-57.

COLAS G., 1975. The use of progestagen SC 9880 as an aid for artificial insemination in ewes. Ann. Biol. anim. Bioch. Biophys., 15, 317-327.

COLAS G., BRICE G., 1976. Seasonal variations of the fertilizing capacity of the deep frozen ram semen. 7th int. Congr. Anim. Reprod. A. I., Vol. IV, 977-980.

COLAS G., BRICE G., 1979. Seasonal variation of the fertilizing capacity of the deep frozen ram semen at the induced cestrus and incidence of photoperiod on the semen quality of the ram Livestock Prod. Sci. (in press).

COGNIE Y., MARIANA J. C., THIMONIER J., 1970. Etude du moment d'ovulation chez la brebis normale et traitée par un progestagène associé ou non à une injection de PMSG. Ann. Biol. anim. Bioch. Biophys., 10, 15-24.

DACHEUX J. L., O'SHEA T., PAQUIGNON M., 1978. Effects of osmolarity, bicarbonate and buffer on the metabolism and motility of testicular epididymal and ejaculated sperm of boar. $J$. Reprod. Fert. (in press).

DAUZIER L., 1958. Physiologie du déplacement des spermatozoïdes dans les voies génitales femelles de la brebis et de la vache. Ann. Zootech., 7, 281-351.

ESNAULT C., COUROT M., ORTAVANT R., 1975. Transport and maturation of epididymal spermatozoa. In E. S. E. HAFEZ, C. G. THIBAULT, The biology of spermatozoo. S. Karger, A. G. Basel.

FOURNIER S., 1968. Mise en évidence électrophorétique d'une glycoprotéine acide du sperme épididymaire et migrant rapidement vers l'anode d̀ pH 8,45. C. R. Soc. Biol., 166, 558-563.

FOURNIER-DELPECH, S., BAYARD F., BOULARD D. L., 1973. Isolement, extraction et caractérisation d'une sialoprotéine du sperme épididymaire du rat par électrophorèse sur polyacrylamide. C. R. Soc. Biol., 167, 543-547.

FOURNIER-DELPECH S., BAYARD F., BOULARD L., 1974. Ełude d'une protéine spécifique du sperme épididymaire chez le rat; hormonodépendance; relation avec l'acide sialique. $C$. $R$. Soc. Biol., 168, 1989-1996.

FOURNIER-DELPECH S., COLAS G., COUROT M., ORTAVANT R., 1977. Observations on the motility and fertilizing ability of ram epididymal spermatozoa. Ann. Biol. anim. Bioch. Biophys. 17, 987-990.

GLEDHILL B. L., 1971. Studies on the DNA content dry mass and optical area of bull spermatozoa during epididymal maturation. Acta vet. scand., 7, 131-142.

GORDON L., 1975. The use of progestagens in sheep bred by natural and artificial insemination. Ann. Biol. anim. Bioch. Biophys., 15, 303-316. 
HOLTZ W., SMIDT D., 1976. The fertilizing capacity of epididymal spermatozoa in the pig. J. Reprod. Fert., 46, 227-229.

HUNTER R. H. F., HOLTZ W., HENFREY P. J., 1976. Epididymal function in the boar in relation to the fertilizing ability of spermatozoa. J. Reprod. Fert., 46, 463-466.

KILLEN I. D., MOORE M., 1971. The morphological appearance and development of ova sheep fertilized by surgical insemination. J. Reprod. Fert., 24, 63-70.

KOSKIMIES A. I., KORMANO M., 1975. Proteins in fluids from different segments of the rat epididymis. J. Reprod. Fert., 43, 345-348.

LIGHTFOOT R. J., SALAMON S., 1970. Fertility of ram spermatozoa frozen by the pellet method. II. The effects of method of insemination on fertilization and embryonic mortality. J. Reprod. Fert., 22, 399-408.

MARUSHIGE Y., MARUSHIGE K., 1975. Transformation of sperm histone during formation and maturation of sperm of rat. J. biol. Chem., 10, 39-45.

ORGEBIN-CRIST M. C., 1969. Studies on the function of the epididymis. Biol. Reprod., Suppl. 1, 155175.

ORGEBIN-CRIST M. C., DANZO B., DAVIES J., 1975. Endocrine control of the development and maintenance of sperm fertilizing ability in the epididymis, 319-338. In HAMILTON D.W., GREEP R. O., Handbook of Physiology, Sect. 7, Endocrinology, Vol. 5, Am. Physiol. Soc., Washington DC.

ORGEBIN-CRIST M. C., DANZO B., COOPER T. G., 1976. Re-examination of dependance of epididymal sperm in the epididymal environment. J. Reprod. Fert., 24, 115-118.

ORGEBIN-CRIST M. C., JAHAD N., 1977. Delayed cleavage of rabbit ova after fertilization by young epididymal spermatozoa. Biol. Reprod., 16, 338-362.

ORTAVANT R., 1953. Existence d'une phase critique dans la maturation épididymaire des spermatozoïdes de bélier et de taureau. C. R. Soc. Biol., 147, 1952-1956.

ORTAVANT R., DUPONT S., PAUTHE H., ROUSSEL, 1953. Contribution à l'étude de la différenciation des spermatozoïdes morts el vivants dans le sperme de taureau. Ann. Zootech., 2, 1-8.

ORTAVANT R., 1958. Le cycle spermatogénétique chez le bélier. Thèse Doct. ès Sci., Ann. Zootech., $1959,2,183-271$ et 271-322.

OSCAR A. L., PETRUSZ P., FRENCH F. S., 1978. Purification and localization of acidic epididymal glycoprotein (AEG) : a sperm coating protein secreted by the rat epididymis. 5th onnu. workshop on the testis. Int. J. Andrology, Suppl. 2, 1-13.

OVERSTREET J. W., BEDFORD J. M., 1976. Embryonic mortality in the rabbit is not increased after fertilization by young epididymal spermatozoa. Biol. Reprod., 15, 54-57.

PAZ G., KAPLAN R., YEDWAB G. Y., HOMONNAI Z. T., KRICER P. F., 1978. The effect of caffein on rat epididymal spermatozoa : motility, metabolism and fertilizing capacity. Inter. $J$. Androl., Suppl. 1, 145-152.

TERQUI M., THIMONIER J., 1974. Nouvelle méthode radioimmunologique rapide pour l'estimation du niveau de progestérone plasmatique. Application chez la brebis et chez la chèvre. C. $R$. Acad. Sc. Paris, Série D, 279, 1109-1112.

UERAHA T., YANAGIMACHI R., 1977. Behavior of nuclei of testicular caput and cauda epididymal spermatozoa injected into eggs. Biol. Reprod., 16, 315-321.

VOGLMAYR J. K., 1975. Metabolic changes in spermatozoa during epididymal transit, 451-487. In HAMILTON D. W., GREEP R. O., Handbook of physiology, Sect. 7, Endocrinology, Vol. 5, Amer. Physiol. Soc., Washington DC.

WINTENBERGER-TORRES S., 1978. Rôle actif de l'embryon avec l'implantation, 181-192. In du MESNIL du BUISSON F., PSYCHOYOS A., THOMAS K. L'implantation de I'œuf. Masson, Paris. 